4. 大学病院医療情報ネットワーク

開 原 成 允 (東京大学医学部附属病院中央医療情報部)

情報システムは，小さなシステムから多くの部門を含む大きなシステムへと発展していく．医療情 報システムも最初は事務部門や検查部門などの単独部門のシステムから出発して，それらの部門を連 結する病院全体のシステムへと発展してきた。日本の医療は全国的に共通な制度下に行われているか ら，そこで使用されている情報には共通のものが多くある，例えば保険請求に関するデータ，薬剤や 検查に関する情報，教科書的な医学知識などである，従って，病院内のみでなく医療機関を連結する ような情報システムを作って，その間で共通のデータを交換できるようにすると多くの利点があると 考穴られる.

一方，異機種のコンピュータを連結し，ネットワークとする技術は次第に発達しつつあり，基本的 なデータの交換は可能となった.

このような環境を考えて，国立大学病院では，医療情報部門の連絡会議を通じ，大学病院のコンピ ュータを連結するネットワークの構築を文部省に依頼していたが，幸いその理解を得て，1988年度に センターコンピュータの予算が認められ東京大学病院内にそれが設置された。更に，1989年度からは， 数大学病院づつネットワークに連結するための予算が認められ, 1992年 1 月現在, 北海道, 弘前, 東 北, 新潟, 筑波, 東京, 群馬, 千葉, 信州, 金沢, 名古屋, 京都, 大阪, 神戸, 岡山, 鳥取, 広島, 愛媛, 九州, 熊本, 長崎, 鹿児島, 琉球の 23 大学病院が連結されている. また, 私立大学病院からも 個人利用者を受け付けており, 数大学病院に利用者がある.

現在このネットワークで可能な機能は，第一に共通データの提供である．医療関係のデータとして は，保険点数マスター，薬剤情報，病名マスター，などがあり，備品などのコード表なども予定され ている. 医学知識データとしては，内外の各種のデータベースがこのネットワークを介して直接（例 えば病棟の端末からも) 利用でさるよらになる.データベースとしては, 学術情報センターのデータ ベース，海外のデータベースなどと契約が結ばれている．第二は，大学病院職員の間の連絡で，この ための電子メールや揭示板が用意されて怙り，電子メールは，海外の BITNET， INTERNET とも 連結されている. 第三は，これを介した情報の収集である. 現在大学病院の間では，各種の統計や研 究データが集められているが，これもネットワークを介して収集が可能になる予定である.

技術的には，現在のプロトコールは「I N」，将来は「OSI」に移行の予定である. 回線は「学術情 報センター」の保有する学術情報ネットワークの回線の中に閉域網も定義して利用している.また， プライバシー保護の観点から，アクセスできるのはセンターコンピュータのみであり, 各大学病院の コンピューターは, 他の大学病院の利用者は入れないよらになっている.

\title{
5. 臓器移植ネットワーク
}

\section{野 瀬 善 明（九州大学医学部医療情報部）}

移植は拒絶反応を起こさない免疫特異性のマッチングする移植希望者を公正・公平に選ぶことが大 切です．日本は国土が狭く，全国どこにでも短時間に蔵器を移送できますので日本で, 一番良くマッ チする移植希望者を見つける民営の全国ネットワークをつくることが大切です．臓器移植の関係団体 を民営化することは，一見移植を商業化して不公正・不公平なるのにする原因となるよらに思えます が，実は民営化してこそ国民の希望に沿って柔軟に運営方針を変更する公正・公平な運営が可能とな 